This item was submitted to Loughborough's Research Repository by the author.

Items in Figshare are protected by copyright, with all rights reserved, unless otherwise indicated.

\title{
Strategy development: driving improvisation in Malaysia
}

PLEASE CITE THE PUBLISHED VERSION

http://dx.doi.org/10.1016/j.jwb.2015.07.002

\section{PUBLISHER}

(C) Elsevier B.V.

\section{VERSION}

AM (Accepted Manuscript)

\section{PUBLISHER STATEMENT}

This work is made available according to the conditions of the Creative Commons Attribution-NonCommercialNoDerivatives 4.0 International (CC BY-NC-ND 4.0) licence. Full details of this licence are available at: https://creativecommons.org/licenses/by-nc-nd/4.0/

\section{LICENCE}

CC BY-NC-ND 4.0

\section{REPOSITORY RECORD}

Hodgkinson, lan, Paul Hughes, and Darwina A. Arshad. 2015. "Strategy Development: Driving Improvisation in Malaysia”. Loughborough University. https://hdl.handle.net/2134/18864. 


\title{
Strategy development: Driving improvisation in Malaysia
}

\author{
Ian R. Hodgkinson ${ }^{1}$ \\ The School of Business and Economics, Loughborough University, Loughborough, United \\ Kingdom. \\ Leicestershire LE11 3TU, United Kingdom \\ Tel: +44 (0)1509 223865 \\ Email: I.R.Hodgkinson@lboro.ac.uk. \\ Paul Hughes \\ The Business School, Durham University \\ Mill Hill Lane, \\ Durham DH1 3LB, United Kingdom. \\ Tel: +44 (0) 1913345393. \\ Email: Paul.Hughes@durham.ac.uk. \\ Darwina Arshad \\ School of Business Management, \\ University Utara Malaysia. \\ 06010 UUM Sintok, \\ Kedah Darul Aman, Malaysia \\ Email: Darwina@uum.edu.my \\ ${ }^{1}$ Corresponding author
}

\begin{abstract}
Improvisation is vital for strategy development, but there remains a lack of understanding about this phenomenon. This emerges directly from the insufficient investigation of its drivers and context. This paper extends improvisation research to the unexplored competitive settings of an emerging middle-income economy. Drawing on survey data from Malaysian research-intensive firms, we examine managerial and organizational antecedents of improvisation under turbulence. Findings reveal that organizational risk-taking and manager expertise are common antecedents of improvisation, but additional relationships arise under high (flexibility) and low turbulence (learning, manager tenure), developing capacity to inform practice, which is critically lacking in international business and management theory.
\end{abstract}

Keywords: emerging economy, improvisation, Malaysia, middle-income, strategy, turbulence, 


\section{Introduction}

Organizational improvisation has emerged as a very important phenomenon in the business arena, enabling manager spontaneity to enable change as circumstances evolve (Eisenhardt, 1997). Defined as the substantive merger of planning and execution outside the formal cycle of planning (Kyriakopoulos 2011; Miner, Bassoff, \& Moorman, 2001; Vera \& Crossan 2004), there remains a lack of understanding about the phenomenon (Vendelø, 2009), emerging directly from the insufficient investigation of its drivers and context in the international business and management literatures (Kyriakopoulos, 2011).

Improvisation theory proposes that firm characteristics can drive action and execution, but this assumes that firms with high or low improvisation share simply high or low levels of the same internal characteristics. Furthermore, research into improvisation typically has not examined antecedent factors but rather has concentrated on outcomes of improvisation (e.g., Nemkova et al., 2012). Despite the environmental context from which improvisation emerges being a key theoretical contingency (Chelariu, Johnston, \& Young, 2002; Vendelø, 2009), extant improvisation research has also been biased towards study in high-velocity markets of developed economies (see Aram \& Walochik, 1996; Cunha, 2005). As a result, the drivers of improvisation in the different competitive settings of emerging economies remain unexplored. With higher levels of uncertainties than their peers in developed economies and greater frequency of surprising events, arising from rapid and chaotic environmental changes (Zheng \& Mai, 2013) the apparent need for firms to adapt to their environment gives rise to our research question: what drives organizational improvisation in an emerging economy under conditions of turbulence?

Focusing on this research question, we argue that managerial and organizational characteristics directly affect organizational improvisation, and also competitive turbulence impacts the relationships between different internal characteristics and improvisation in different ways. This article thus responds to calls for research issued by Nemkova et al. (2012) for study into the antecedents of improvisation, and by Kyriakopoulos (2011) and Wright, Filatotchev, Hoskisson, and Peng (2005) to extend the study of strategy and organizations to a wider range of settings to examine the extent to which theories in developed economies are suited to the characteristics and actions of firms in emerging economies. 
We test our hypotheses using survey data generated from Malaysian research-intensive organizations, including high technology, biotechnology, information technology/information communication technology, and telecommunications. Such industries have been successful in driving that country's economic growth and have undergone substantial shifts from low-cost, export-orientation to higher value-added, more capital-intensive industrialization as supported by governmental policy (Todd \& Peetz, 2001). Yet Malaysia remains mired in the middle-income trap (Gill \& Kharas, 2007). With aspirations of becoming a high-income country, Malaysian organizations are encouraged to focus on innovation and innovative organizational processes (Ahlstrom, 2010; Alvarez, Barney \& Newman, 2015). Organizational improvisation represents such an approach to innovation and strategic decision-making and thus encouraging firm growth.

To study this, the paper conducts multiple regression analysis of the survey data drawn from 128 Malaysian private firms to identify organizational and managerial antecedents of improvisation. Additional analysis is presented by means of an ANOVA test to uncover differences between groups of high and low improvising firms on these internal characteristics. The paper's findings reveal that organizational risk-taking and managerial expertise are common antecedents of improvisation, but additional relationships arise under high (flexibility) and low turbulence (learning, manager tenure).

Overall, this article makes four contributions. First, in recognition that the establishment of certain structures and practices are likely to enable improvisation (Hadida, Tarvainen, \& Rose, 2014), to the best of our knowledge, we are the first to examine key managerial (tenure, expertise) and organizational (risk-taking, flexibility, learning) characteristics collectively as antecedents of improvisation. Second, environmental disruptions are suggested to compel organizations to improvise (Hadida et al., 2014). To the best of our knowledge, we are the first to examine the influence of high and low levels of competitive turbulence simultaneously on the drivers of improvisation, thus extending theory beyond a bias to study high-velocity markets (Kyriakopoulos, 2011). Third, whether theoretical propositions and initial findings in Western economies translate across into emerging economy contexts is uncertain (Wright et al., 2005). This paper is perhaps the first to extend improvisation theory to understand how firms improvise in middle-income, emerging economies that have been neglected in improvisation theory. Finally, we offer an empirical contribution providing much needed evidence of antecedents (Nemkova et al., 2012) to move theory beyond anecdotal, metaphorical, and theoretical 
propositions, highlighted as an important priority for the field (Hadida et al., 2014; Vendelø, 2009; Vera \& Crossan, 2004). These contributions enhance our capacity to inform practice on the incidence and triggers of improvisation, which is lacking in international business and management literatures (Abrahamson, 2008; Kyriakopoulos, 2011).

\section{Improvisation theory}

Despite rapid advances in information technology, access to full or near-full information is still realistically impossible as the opportunity costs and time costs of information generation, analysis, and interpretation is often too great (March, 1994). Given the nature of these demands and the limited timeframe in which decisions are typically made, it is unsurprising that managers' information processing capacities are taxed or exceeded (Hodgkinson, Sadler-Smith, Burke, Claxton, \& Sparrow, 2009). Managers’ capacities to make effective decisions are constrained by bounded rationality, whereby responses and strategic choices are made with respect to a very limited and simplified view of the real situation. This highlights the role of intuition as a means to deal with excessive information-processing demands, arriving at plausible courses of action based on 'knowing how or what' but without knowing why (Ahlstrom \& Nair, 2000; Hodgkinson et al., 2009). Organizational decision making then is increasingly seen as intuitive, rarely rational and logical (Bakken, 2008), spontaneous (Vera \& Crossan 2004), and reliant on novel ideas that are executed as they unfold (Moorman \& Miner, 1998b), otherwise described as improvisation (see Nemkova et al., 2012).

The improvisation theory development effort is limited (Kyriakopoulos, 2011) and is evident at both the country and organizational levels. First, in terms of country settings, existing studies of improvisation are set in developed economies such as Portugal, Spain, France, UK, and Holland (Aram \& Walochik, 1996; Cunha, 2005; Kyriakopoulos, 2011; Nemkova et al., 2012) at the neglect of emerging economies, despite these economies assuming an increasingly prominent position in the world economy (Wright et al., 2005). As a result of this bias, there is a clear need to examine strategic processes such as improvisation in different country settings beyond Western economies (Young, Tsai, Wang, Liu \& Ahlstrom, 2014). Extending improvisation thought, however, from Western to Eastern economies may not translate because of significant differences in organizational characteristics and managerial practices between the cultures, such as traditional respect for age, hierarchy and authority, paternalism and 
collectivism, conformity rather than individuality, and centralization of decision-making (Tsai, Hung, Kuo, \& Kuo, 2006). As emerging economies move toward more market oriented institutions, however, business practices may need to adapt in order to access the resources and capabilities necessary to succeed in a more developed market environment (Acemoglu \& Johnson, 2005; Wright et al., 2005). Organizational improvisation may be a means to overcome barriers to change, such as inertial forces in emerging economies (Li \& Tang, 2010), facilitating strategy emergence (Kyriakopoulos, 2011). Second, at the organizational-level, there is a tendency in the literature to study improvisation in turbulent settings on the assumption that “...the higher the speed of the environment framing the organization, the higher the likelihood of it undertaking improvisational activities” (Cunha et al., 1999, p. 317). Miner et al. (2001) note that improvisation often emerges when organizations face time pressures, as such the majority of extant improvisation research has focused on organizations in fast-moving settings such as entrepreneurial settings and high-technology industries (Bingham, 2009; Magni et al., 2009). In effect, most previous research has been conducted in settings where improvisation is more likely to occur with the majority of focus given to outcomes (e.g., Nemkova at al., 2012), without efforts to explain how it might occur. Collectively, the lack of research in alternative settings has limited the usefulness of the phenomenon to strategic managers and as a result “...our capacity to inform practice on the incidence and value of improvisation is crippled” (Kyriakopoulos, 2011, p. 1052). Relative to existing research then, there is a need to examine antecedents of improvisation against the characteristics of firms in emerging economies.

Improvisation theory has typically relied on artistic metaphors to articulate and position research investigations. Such studies have particularly drawn on jazz (Eisenhardt, 1997), improvisational theatre (Vera \& Crossan, 2004), and Indian music (Kamoche, Cunha, \& Cunha, 2003) to suggest ongoing acts of improvisation. Such efforts represent an attempt to transpose to organizational contexts the characteristics of improvisation inherent in the arts (Cunha, Cunha, \& Kamoche, 1999). This approach to examining improvisation has, however, not been without its critics with suggestions that such metaphors hamper new insights about improvisation in organizations (Vendelø, 2009). More recently, the improvisation literature has moved away from the arts in examining this phenomenon in organizational settings, such as new product development (Eisenhardt \& Tabrizi, 1995; Kyriakopoulos, 2011), export decision making (Nemkova et al., 2012), foreign market entry (Bingham, 2009), and corporate restructuring 
(Bergh \& Ngah-Kiing Lim, 2008). Such studies have established that improvisation is not automatic in business settings and may be influenced by both the internal characteristics of the firm as well as environmental conditions.

The 'black box' of improvisation in organizations thus remains largely unopened (Vendelø, 2009). Though work on improvisation is still in its infancy, there have been several noteworthy theoretical investigations, for example, Moorman and Miner (1998a) conceptualise the development of organizational improvisational competencies. Cunha et al. (1999) and Gibbons and O'Connor (2005) propose internal triggers of improvisation that include organizational structure, top management experience and expertise, while Chelariu et al. (2002) discuss how environmental uncertainty, dynamism and complexity influence the effectiveness of improvisation. Despite these efforts, improvisation research remains at an immature stage with just a few empirical studies available (Magni, Proserpio, Hoegl, \& Provera, 2009; Vendelø, 2009). For example, Moorman and Miner (1998b) test the influence of environmental and organizational factors on the occurrence of improvisation in new product actions, reporting that organizational memory level decreases, while environmental turbulence level increases, the incidence of improvisation. Kyriakopoulos (2011) reports a negative relationship between improvisation and market effectiveness that is weakened by market information flows and stored knowledge. While Nemkova et al. (2012) examine the relationship between improvisation, decision-making, and improved export performance. Nevertheless, improvisation research is yet to develop a more nuanced theory of the role of different internal characteristics in driving improvisation under different environmental conditions.

The previous studies typically depict a known instance of improvisation and trace its positive links to other organizational actions and outcomes (Hadida et al., 2014). However, there is variation in the direction of results presented (e.g., Kyriakopoulos, 2011) and in the strength of findings reported, illustrating the ambiguity still surrounding this phenomenon. Rather than examine outcomes of organizational improvisation, it is by necessity that its antecedents are investigated if improvisation theory is to be developed. Emergent strategy development is suggested to occur inadvertently, without the planned intentions of managers (Mintzberg, 1994), yet improvisation is suggested to enable firms to manipulate and build on their emergent actions and environmental opportunities as they manifest (Hadida et al., 2014). However, the achievement of this is little understood beyond theorization or conceptual development, with 
antecedents of improvisation largely unknown. Improvisation theory needs to establish how improvisation is driven as a conscious act of emergent strategy. Thus, if the institutionalization of structures and/or management practices enable improvisation within the organization (Hadida et al., 2014), then the question remains as to what these structures and practices comprise?

We examine two groups of Malaysian research-intensive organizations. The first group of firms face high competitive turbulence and operate within an unpredictable competitive setting; the second group of firms face less competition and operate within a more predictable competitive environment. In doing so, we seek to reveal contrasts in antecedents of improvisation across divergent competitive situations. Our interest lies in the internal characteristics of these groups of organizations and in particular what organizational and managerial characteristics might drive improvisation, and at different levels of turbulence (as shown in Figure 1). Organizational characteristics likely dictate in some respects the range of strategic alternatives available to an organization when responding to environmental pressures (Slevin \& Covin, 1997); while, the characteristics of managers are likely to influence individual actions taken during the execution of strategy in response to the environment (Weick, 1998). Thus, there are clear links between organizational and managerial characteristics, environmental turbulence and the propensity for improvisation that warrant investigation.

--Insert Figure 1 about here--

\section{Hypothesis Development}

\subsection{Organizational Characteristics}

We consider organizational risk-taking, flexibility, and learning as organizational characteristics that may be influential drivers of improvisation. Organizational risk-taking relates to experimentation where the organization has to encourage experimentation and tolerate errors (Cunha et al., 1999; Hamel, 2012). This is determined by the decisions of organizational actors that are charged with investing resources in activities with uncertain outcomes (Baird \& Thomas, 1985). Uncertainty and risk-taking are fundamental to decision making and firm survival, whether in a collectivist or more individualist society (Li \& Tang, 2010). The risk laden nature of simultaneously taking and implementing actions made with limited information, under time pressures and clouded in uncertainty means improvisation is likely to be influenced by organizational predispositions to risk (e.g., Cunha \& Cunha, 2003). Indeed, thinking outside of 
previous plans and previously tested solutions implies risks (Moorman \& Miner, 1998a). Weick (1998) suggests that without a positive attitude towards risk, improvised actions cannot occur. This supports the proposition that a favourable approach to risk may be a necessary condition for organizational improvisation in spite of competitive turbulence. While risk-taking and riskseeking have been examined in settings such as China and Japan, respectively (Greve, 2003; Li \& Tang, 2010), there is no evidence of its link to improvisation.

Risk-taking propensity, then, is positively related to improvisation, irrespective of the environment conditions, however subsequent organizational and managerial variables will be more affected by competitive turbulent conditions as informed by improvisation literature. High competitive turbulence demands risky strategic shifts by firms to respond to rapid changes in the task environment and to sustain competitiveness; while under conditions of low competitive turbulence, the instances where improvisation occurs around (or in the context of) a plan can be useful for more tactical decisions due to the responsiveness afforded by spontaneous action (Nemkova et al., 2012). There is expected to be greater propensity of tactical (operational) decisions made, which are less risky, but address immediate issues and actions to be taken to achieve pre-established goals and objectives. Notwithstanding competitive turbulence, organizational risk, then, encourages thinking 'outside the box' that can occur both within and outside of pre-determined parameters of a plan (Moorman \& Miner, 1998a). Accordingly we hypothesize:

Hypothesis 1. Organizational risk-taking is positively related to improvisation under both high competitive turbulence and low competitive turbulence.

To improvise successfully is suggested to be dependent on organizational flexibility. Flexibility reflects a firm’s ability to operate responsively in a rapidly changing environment through individuals (Atkinson, 1985). Indeed, organic structures characterized by decentralization and informal rules and procedures tend to promote greater flexibility (Krohmer, Homburg, \& Workman, 2002), while inflexibility is true of the opposite (Slevin \& Covin, 1997), that is, centralization, bureaucracy and formalization is suggested to impede organizational flexibility (Hughes, Hughes, \& Morgan, 2010). In the emerging economy context, centralization is inherent in business practice (Tsai et al., 2006) with lower-levels of management given minimal autonomy for decision-making (Chi, Huang, \& Lin, 2009). However, managerial 
discretion—a manager's latitude of action—varies between executives (Li \& Tang, 2010), thus centralized structures may still enable organizational flexibility. For example, Cunha et al. (1999) contend that improvisation can occur within organizations characterized by direct supervision and standardized co-ordination mechanisms. Nevertheless, it would be expected that under low competitive turbulence firms maintain control and consistency over strategic direction (Covin, Slevin, \& Schultz, 1997). In the Asian context, when firms have more inertia under conditions of stability, the managerial discretion of executives is weakened which may reduce flexibility (Li \& Tang, 2010; Liu, Wang, Zhao \& Ahlstrom, 2013).

Inflexibility is of less concern for improvisation under low competitive turbulence as strategy remains relatively consistent and unchanged over time (Hughes et al., 2010). Under low competitive turbulence a "clearly articulated strategy and goals serve the all-important function of ensuring that improvisational activity amounts to the attainment of organizational objectives” (Cunha et al., 1999, p. 320). Here, improvisation is not driven through a flexible approach to strategy, however, the faster a competitive environment is, the faster the firm must respond to changes (Mintzberg, 1979). As such inflexibility may not be a barrier to improvisation for firms operating under low competitive turbulence. In contrast, this is likely to be problematic for firms facing high competitive turbulence that require greater flexibility to nurture improvisation, where speed is a competitive weapon. Therefore we hypothesize:

Hypothesis 2. Organizational flexibility is a) positively related to improvisation under high competitive turbulence but is $\mathbf{b}$ ) negatively related to improvisation under low competitive turbulence.

Given that improvisation both departs from existing knowledge while building on that knowledge (Cunha et al., 1999), it follows that organizational learning will influence the occurrence of improvisation. Organizational learning is a process that involves the discovery, retention and exploitation of stored knowledge (Chelariu et al., 2002), which increases the firm's awareness and alertness during improvisation to deal with unexpected events (Kyriakopoulos, 2011). Organizational learning then is a key driver of successful improvisation, and is “...likely to be continuous and circular, occurring as improvisation occurs and being immediately used as part of the process” (Chelariu et al., 2002, p. 142). 
In benign and familiar environments, organizations may favor routine information searching, while in response to significant external changes, more intensive forms of knowledge acquisition are likely to guide improvisation. The potential for learning effectiveness, however, may be limited in collectivist contexts where decisions are centralized and dominated by highstatus managers to the exclusion of other organizational members, resulting in reduced creativity (Chi et al., 2009) and thus increased improvisation. However, Chinese firms that utilize learning mechanisms to store knowledge and provide access to existing knowledge stocks for decisionmakers have been found to improvise in response to surprising events (Zheng \& Mai, 2013). While organization-wide learning may occur to a lesser extent in this context relative to Western economies that have higher levels of decentralization, it is likely to increase instances of improvisation by helping key decision-makers to have information and knowledge at hand to make and execute decisions rapidly (e.g., Kyriakopoulos, 2011). Following improvisation theory, therefore:

Hypothesis 3. Organizational learning is positively related to improvisation under a) high competitive turbulence and b) low competitive turbulence.

\subsection{Managerial Characteristics}

This paper also examines tenure and expertise as key managerial characteristics. The role of experience is often associated with the description of successful improvisational events (Vera \& Crossan, 2005). Leybourne and Sadler-Smith (2006) demonstrate that experienced managers are more prone to improvise than their less experienced counterparts. Similarly, Gibbons and O'Connor (2005) identify that the greater the experience of the CEO, the smaller the degree of formalized planning occurrences. Intuitive responses depend upon the patterns of managerial experience in a given domain (Crossan \& Sorrenti, 2002). It follows then that managers of high tenure in Western economies are more likely to pursue intuitive behaviour and therefore display a propensity for improvisation. For example, Nemkova et al. (2012) illustrate how knowledge accumulated during years of employment allows quicker understanding and reactions to problems. However, while high-tenured mangers are prevalent in Asian firms there is a greater propensity for long range planning, rather than the intuitive responses (Tsai et al., 2006) seen in Western settings. This does however support Hambrick and Fukutomi's (1991) suggestion that the longer or higher the tenure of top managers, the more likely they are to rely on past decisions 
to inform future actions. This can result in managerial unwillingness to deviate from their historic decisions and in turn constrain their capacity for change (Hughes et al., 2010), or improvisation. This is consistent with research examining CEO tenure and strategic fit, “...as environments change, many organizations run by long-tenured CEO's fail to change with them" (Miller, 1991, p. 49). High tenure, then, may exacerbate a tendency to adhere to strategy and act in narrowly conceived ways (Hughes et al., 2010). This effect is likely to be the case under conditions of high competitive turbulence where significant external shifts demand short-term adaptability that is critical to competitiveness. In contrast, conditions of low competitive turbulence may provide the necessary incentive for long tenured managers' spontaneous idea creation and execution, since tenure diversity can damage the output of creative thoughts in collectivist contexts (Chi et al., 2009). Thus:

Hypothesis 4. Managerial tenure is a) negatively related to improvisation under high competitive turbulence but is $\mathbf{b}$ ) positively related to improvisation under low competitive turbulence.

While improvisation may be conceived as unpredictable, considerable human infrastructure underlies its realization including members' expertise (Vera \& Crossan, 2005). Expertise encompasses specialized skills and knowledge of members and comprises domainrelevant and task-related skills that depend on innate cognitive abilities, innate perceptual skills, experience, and formal and informal education (Vera \& Crossan, 2004). In the manufacturing industry, Li and Tang (2010) identify that Chinese executives with both industry experience and a formal education are more inclined to risky decision making, a favourable condition for improvisation as opposed to longer range planning. While we acknowledge industries within emerging economies will vary significantly in level of skill intensity (Liu, Hodgkinson, \& Chuang, 2014) that may influence the way in which decision-making occurs at the firm-level, by targeting research-intensive firms in Malaysia we expect expertise to be present given that comparable high-technology organizations in similar emerging economies (e.g., Taiwan) are a source of innovation in the global market place (Chi et al., 2009), for which expertise, or skill intensity is a necessity (Liu et al., 2014).

Outside of the improvisation literature, it has been suggested that when experts recognize that their habitual responses are incompatible with new rules, their potential for setting aside or 
altering these habits may be limited (Dane, 2010). Nevertheless, expertise has been shown to have a positive impact on individual attitudes toward improvisation through the development of individual confidence to improvise (Magni, Provera, \& Proserpio, 2010). Skilled managers typically utilize their expertise on a real-time basis for intuitive responses, thus the larger and more diverse the skill-base, the more alternatives for developing new combinations of ideas (Cunha, Kamoche, \& Cunha, 2002 Vera \& Crossan, 2004). The expertise of organizational members then can be viewed as an important driver of improvisation (Leybourne \& SadlerSmith, 2006; Vera \& Crossan, 2005). Accordingly we hypothesize:

Hypothesis 5. Managerial expertise is positively related to improvisation under a) high competitive turbulence and $\mathbf{b}$ ) low competitive turbulence.

\section{Research Method}

\subsection{Data generation}

Data was generated through a survey of 1081 research-intensive Malaysian private firms randomly selected from The Federation of Malaysian Manufacturer directory, Malaysia Biotech Corporation directory, MSC Status directory and the MESDAQ directory of Malaysian organizations. Malaysian research-intensive organizations are categorised into four industries, namely, high technology (32.8\%), biotechnology (8.6\%), information technology/information communication technology (51.6\%), and telecommunications (7\%). The average age of the respondent organizations is 16.62 years with average sales turnover at US\$171.95m. We do not distinguish here between domestic firms and foreign invested enterprises (c.f. Liu et al., 2014), or family firms versus non-family firms (c.f. Tsai et al., 2006) as we seek to address more broadly what drives organizational improvisation in an emerging economy under varying conditions of turbulence. Organizational forms included within the directories, such as incubators and higher learning institutions, that have government involvement in their operation and ownership, were excluded from the study since competitive turbulence and the drivers of improvisation may vary between private/public contexts. These organizations are sampled at the SBU level as they compete through product-market strategies and because organizational improvisation is observed at this level. Senior decision-makers (e.g., Chief Executive Officer, Chief Operating Officer, Managing Director) were targeted as the key informant since these 
decision-makers have: most knowledge of the strategic decision-making process; insight into the creation of strategy; and could provide reliable information regarding the firm's characteristics.

Pre-testing the questionnaire through a panel of eight scholars from both the UK and Malaysia and twelve managers from Malaysian private firms led to minor adjustments to the questionnaire items to ensure acceptable face and content validity. Survey administration consisted of a five stage protocol of pre-notification, a full questionnaire pack, and first reminder letter, second reminder consisting of a full questionnaire pack, and telephone contact with one hundred random sampled non-respondents. Recommendations regarding cover letter, questionnaire length, return postage, follow-ups, anonymity, lack of explicit deadlines, and university sponsorship were applied. 291 responses were obtained yielding a response rate of 27\%. In order to avoid confounding results, 163 firms that were included had either ceased operation or had missing data so were eliminated from the analysis, which focused on the remaining 128 firms. Non-response bias was examined for and statistical comparisons between early and late respondents reveal no significant differences.

\subsection{Study measures}

All measurement scales are drawn from previous studies and align with the definitions of the constructs examined. Measures of organizational improvisation were created by the research team based on the definition of the construct and the work of Nemkova et al. (2012). Measures of organizational learning and manager expertise were adapted from similar items used by Vera and Crossan (2005). Organizational risk-taking was gauged by employing the approach by Singh (1986). Measures of organizational flexibility and competitive turbulence were adapted from similar items used by Auh and Menguc (2007), Jones, Rafferty, and Griffin (2006), and Krohmer et al. (2002), respectively. Tenure was assessed by asking the respondent to identify their length of tenure with their current organization. A seven-point Likert-type scale was adopted for all items. The precise wording of measurement items are presented in Table 1.

\section{--Table 1 about here--}

To capture competitive turbulence we split the sample to examine the hypotheses in conditions of high and low levels of competitive turbulence. Turbulence was measured using a 7point Likert-type scale and a split point for the sample was set at a turbulence of 4.70. This resulted in an even sample split and meant that those firms operating in 'high' turbulence were 
indeed operating in such conditions. A lower split level would have introduced firms operating in moderate turbulence into the high turbulence category, which may have introduced confounding effects.

All measures were subjected to confirmatory factor analysis (CFA). The properties of these measurement items as derived through CFA are presented in Table 1 and construct robustness and descriptive statistics are presented in Table 2. The model fit results (LISREL 8.8, maximum likelihood estimation, covariance matrix) demonstrate acceptable fit: $\chi^{2}=233.82$; $\mathrm{df}=$ $174 ; \chi^{2} / \mathrm{df}=1.34 ; \mathrm{RMSEA}=.05 ; \mathrm{CFI}=.97 ; \mathrm{IFI}=.97 ; \mathrm{NNFI}=.97$. All construct reliability and variance extracted values are above accepted thresholds. While the variance extracted for manager expertise is below the preferred 0.5 level we retain this construct as it is still acceptable within minimum thresholds (Hughes et al., 2010). Convergent validity is demonstrated as the path coefficients from each measurement item to their respective latent variable are statistically significant as all items load significantly. The square root of average variance extracted for each construct exceed the correlation values between that construct and all other constructs (Table 2), and so confirms discriminant validity (Hughes, Morgan, \& Kouropalatis, 2008). Taken together, these provide strong evidence for construct validity.

--Tables 1 and 2 about here--

\subsection{Common Method Variance (CMV)}

A single source self-report questionnaire was used to generate data in this study, and a drawback of this approach is that common method bias may underlie the data. We used a number of methods prior to data generation to limit common method bias. In developing the instrument, the directions of Podsakoff, MacKenzie, Lee, and Podsakoff (2003) and Spector and Brannick (1995) for limiting this bias were followed: different response formats were used across questions; guarantees of respondent confidentiality and anonymity were provided to reduce respondent apprehension; assurances to respondents that there were no right or wrong answers were given, placing emphasis on providing genuine answers; the measurement scales were placed in random order; non-idealized responses and wording neutrality were adopted; questionnaire length was reduced; and detailed instructions for its completion were provided. Beyond this, we follow the advice of Conway and Lance (2010) for limiting method problems. 
Firstly, a self-report approach is justifiable as objective data on the focal constructs is unobtainable in Malaysia as well as requiring subjective measurement. For example, the degree of organizational flexibility or improvisation could not be readily assessed objectively. Therefore, and secondly, we avoid conceptual overlap in items used to measure the focal constructs by ensuring clear definitions were used and measurement items clearly address and measure their respective constructs (and as defined). Taken together, these a priori precautions greatly strengthen the survey instrument against potential bias.

Post-hoc tests are conducted to assess method bias, despite the warnings of futility provided by Conway and Lance (2010). First, a Harman single-factor test (Podsakoff et al., 2003) was used whereby all items are specified to load onto a single construct. We conduct the test using exploratory factor analysis with varimax rotation. The factor analysis of all measures simultaneously shows a 6 factor solution (variance explained: 70.30\%) with the largest single factor accounting for merely $14.61 \%$ of the total variance. For robustness, we replicate this test using CFA. The results demonstrate unacceptable model fit and imply that common method concerns are not present: $\chi^{2}=960.91 ; \mathrm{df}=209 ; \chi^{2} / \mathrm{df}=4.60 ; \mathrm{RMSEA}=.17 ; \mathrm{CFI}=.75 ; \mathrm{IFI}=.76$; $\mathrm{NNFI}=.73$. The $\chi^{2} / \mathrm{df}$ ratio exceeds the recommended $\leq 2.00$ cut-off suggested by Bollen (1989), RMSEA exceeds the .08 level of acceptability as suggested by Hu and Bentler (1999), and the fit indices are far below the accepted 0.90 threshold. The model fit statistics along with the EFA results, then, imply a lack of common method problems exist in the data.

Second, a marker variable test was conducted (Lindell \& Whitney, 2001). This test can be used to evaluate error attributable to CMV by estimating and accounting for a common methodrelated correction (Hughes, Morgan, Ireland, \& Hughes, 2014). A marker variable should not be theoretically related or correlated to any other items measured. We identified number of years the firm had been competing in its industry as our marker variable, and non-significant correlations ( $p>0.10)$ were found between this variable and all other study variables. Normally the marker variable test is based upon correlation, where the correlation between the marker variable and the focal variables is subtracted from the correlations among the focal variables to adjust for common method bias (Conway \& Lance, 2010). Conway and Lance (2010) discourage use of this remedy for common method bias however due to problems of correlation estimation. We modify the use of this technique in line with Hughes et al. (2014) and focus on how the covariance between variables is affected by the common method as this is what would be 
directly affected by CMV and is what underlies analysis within LISREL 8.8 (using maximum likelihood estimation) of relationships between latent variables (Hughes et al., 2014). Following the prescriptions of Hughes et al. (2014) and Lindell and Whitney (2001), we created a modified covariance matrix and then respecified the original covariance matrix in the original CFA model with the new CMV-adjusted matrix. The results indicated that with CMV-adjusted covariance, the changes in the measurement model were non-significant as the substitution did not significantly deteriorate fit: $\chi^{2}=240.92 ; \mathrm{df}=174$; $\mathrm{RMSEA}=.055 ; \mathrm{CFI}=.99 ; \mathrm{IFI}=.99$; NNFI $=$ .99. $\left(\Delta \chi^{2}=7.10\right.$ [increase]; $\Delta \mathrm{df}=0 ; \Delta \mathrm{CFI}, \Delta \mathrm{IFI}, \Delta \mathrm{NNFI}=.02$ [positive improvement]). We interpret from these results that after controlling for CMV by adjusting the covariance matrix $\chi^{2}$ and RMSEA did not deteriorate significantly while model fit indices actually improved. Presence of common method bias should have revealed a negative deterioration in these model fit statistics. While the CFA results imply no problems we examine this further by using a partial correlation procedure (Lindell \& Whitney, 2001; Podsakoff et al., 2003) as we use regression for hypothesis testing purposes. We once again use the marker variable and partial out the correlation between the marker variable and all study variables in SPSS 20. The results are found in Appendix A. Comparison of the original results to the results obtained after using the partial correlation procedure with the marker variable reveals no real differences between the two sets of results: no paths lose statistical significance or become different in direction and there are no wild variations in standardized coefficients or t-values. We appreciate the limitations of these techniques as discussed by Podsakoff et al. (2003) and also by Conway and Lance (2010) and their suggestion that these tests could be ignored, but we believe that some attempt to analyze for CMV has merit. The results of these CMV tests indicate that such a bias does not appear to be a threat within our data, although it cannot be discounted completely. Overall, the pre-survey measures taken and post-hoc tests conducted provide confidence that CMV is unlikely to explain the relationships found between the study variables (Hughes et al., 2014; Podsakoff et al., 2003).

\section{Empirical Results}

Multiple regression analysis is used to test the hypotheses in SPSS 20. The regression results are shown in Table 3. Regression Model 1 incorporates the direct effects of organizational and managerial characteristics on improvisation, under high competitive turbulence, and Regression Model 2 tests the same effects, but under low competitive turbulence. Both 
regression models are significant. For Model 1: $F=12.744 ; p \leq .01 ; R^{2}=.52$. For Model 2: $F=$ $13.282 ; p \leq .01 ; R^{2}=.56$. The results are largely consistent with our hypotheses.

--Table 3 about here--

In Hypothesis 1 we proposed that organizational risk-taking would be positively related to improvisation under both high competitive turbulence and low competitive turbulence. There is similarity in the findings between the high $(t=3.47 ; p \leq .01)$ versus low $(t=3.15 ; p \leq .01)$ condition, indicating that the propensity for organizational risk-taking increases the incidence of improvisation, irrespective of the environment conditions. It is clear that an organizational context that supports risk-taking may be critical for improvisation in Malaysian researchintensive organizations.

Hypothesis 2 is partially supported by the findings. We suggested that organizational flexibility would be (a) positively related to improvisation under high competitive turbulence but (b) negatively related to improvisation under low competitive turbulence. In terms of organizations characterized by high competitive turbulence, organizational flexibility is identified as an antecedent of improvisation $(t=3.70 ; p \leq .01)$. Under high competitive turbulence, organizations are required to rapidly respond to various demands of the task environment through improvised action. In benign competitive environments $(t=0.14$; n.s.), flexibility appears to becomes less important for improvisation as strategy remains relatively consistent and unchanged over time, but the relationship is non-significant.

With respect to Hypothesis 3, we again find partial support as findings deviate from expectations. We expected that organizational learning would be a key driver of improvisation, in spite of competitive turbulence, on the basis that extant improvisation literature indicates that activities that apply and integrate knowledge are critical. The inference holds for organizations that are characterized by low competitive turbulence $(t=2.41 ; p \leq .01)$, such that organizational engagement with the learning process drives improvisation. This however is not the case for firms facing high competitive turbulence ( $t=-1.18$; n.s.). Though the relationship is nonsignificant, given the negative t-value it appears that the organizational learning process may restrict improvisation by hindering decision-makers’ ability to use information.

With respect to Hypothesis 4(a), we expected managerial tenure to be negatively related to improvisation under high competitive turbulence, but this relationship is non-significant $(t=$ .02). In contrast we had anticipated that managerial tenure would drive improvisation under low 
competitive turbulence, as predicted in Hypothesis 4(b). Contrary to our expectations, the findings demonstrate that managerial tenure has a significant negative effect on improvisation in low competitive turbulence $(t=-2.80 ; p \leq .01)$.

In Hypothesis 5 we proposed that managerial expertise is positively related to improvisation under a) high competitive turbulence and b) low competitive turbulence, consistent with theoretical propositions in extant improvisation literature. Managerial expertise comprising the domain-relevant and task-related skills of managers, leads to a propensity to improvise under conditions of both high $(t=2.26 ; p \leq .05)$ and low $(t=3.03 ; p \leq .01)$ competitive turbulence but the effect is much greater under the low turbulence condition.

\subsection{Additional analysis}

To understand further the influence of organizational and managerial characteristics on improvisation, we conduct an ANOVA test to examine for differences between groups of high and low improvising firms on these internal characteristics. We also go further and examine some additional organizational and managerial characteristics that may contribute toward explaining improvisation levels in the emerging economy context. We do this so as to determine whether systematic differences exist between these groups. Improvisation groups were again created at a split point of 4.7. The results are shown in Table 4. Statistically significant differences are found between the high and low improvisation groups for organizational risktaking, organizational flexibility, organizational learning, and manager expertise. Low improvising firms systematically exhibit lower levels of these dimensions compared to the high improvisation group. When we consider additional characteristics we find that organization size

and years of operation also contribute to explaining systematic differences between these groups but that the low improvisation group exhibit higher levels of sales turnover and have been operating for longer. While, prima facie, the low improvisation firms seem to be more successful in terms of sales turnover we do note that the high improvisation firms are much younger in nature. Taken together, the results as a whole demonstrate firms are less inclined to improvise when averse to risk-taking, lack flexibility, and engage less in organizational learning. This is compounded by high tenured managers having less expertise. The additional results suggest that firms with higher sales turnover and are older will likely improvise less.

--Table 4 about here-- 


\section{Discussion}

\subsection{Contributions}

In following the extant improvisation literature, we would expect that organizations facing high competitive turbulence are more prone to organizational improvisation. Indeed, environmental turbulence has been proposed as an antecedent to improvisation (Vera \& Crossan, 1999). However, it is evident that improvisation not only occurs in conditions of high turbulence, but also low turbulence, and that some antecedents-managerial expertise and organizational risk-taking-are shared. This is an intriguing finding since improvisation theory assumes that improvisation is only likely to occur under high competitive turbulence (e.g., Bingham, 2009; Cunha et al., 1999; Magni et al., 2009; Miner et al., 200). This then should manifest in different results for high versus low turbulence. Demonstrating that this is not the case questions implicit assumptions in improvisation theory (e.g., Kyriakopoulos, 2011) and demands exploration.

It turns out that managerial expertise is a fundamental driver of organizational improvisation, which calls into question the proposed inflexibility of domain experts with respect to problem solving and creative idea generation (Dane, 2010) supporting conclusions that 'thinking on your feet' is not possible without expertise (Nemkova et al., 2012). As an integral part of the discovery process, managerial expertise is instrumental to innovation in Asia, both at the firm-level (Li \& Tang, 2010) and industry-level (Liu et al., 2014). However, the link between expertise and emergent decision-making has not been considered, but is imperative for improvisation. As such the relationship between improvised decisions and outcomes warrants further investigation. In recognition that the degree or type of expertise may indeed differ in various settings (Leybourne \& Sadler-Smith, 2006) and that the relationship between managerial expertise and improvisation may indeed be curvilinear, there is a need to explore the role of expertise in driving improvisation. While organizational risk-taking may be more prevalent in individualistic Western economies where links to improvisation are established (e.g., Cunha \& Cunha, 2003), few studies have considered organizational risk-taking in a collectivist context (e.g., Li \& Tang, 2010; Greve, 2003) with no investigation of its relationship to improvisation in emerging economies. By addressing these gaps, this study extends the influence of risk-taking in decision-making and its impact on the important improvisation process in an emerging economy. To extend theory on improvisation further, research should also account for interaction effects 
between expertise and risk-taking. For example, as expertise increases so might managerial hubris leading to overconfidence and undue risk-taking, increasing the propensity to improvise but endangering firm survival (Li \& Tang, 2010).

Organizational-level improvisation is suggested to contribute to, and is an outcome of, organization absorptive capacity for new knowledge and structural flexibility (Hadida et al., 2014). In highly competitive environments the rate of learning has been proposed to be an important condition for improvisation (Eisenhardt \& Tabrizi, 1995), but our findings do not support this assertion. As noted by Vendelø (2009), learning and improvisation may affect one another negatively. Due to the unpredictable nature of such environments, organizations are forced to constantly change and adapt through improvisation placing a greater need on flexibility as a necessary antecedent rather than organization-wide learning. Since organizational learning requires time to process and assimilate new information, organization-wide information processing activities may impede speed of decision-making, and in turn improvisation. Moreover, centralization of decision-making in Asian firms (Ahlstrom, Young, Chan \& Bruton, 2004; Tsai et al., 2006) may afford firms with greater flexibility under high turbulence as decisions are taken by key decision-makers, with minimal organization-wide knowledge application. Large teams, for instance, hinder decision-makers' ability to get the required information in a short time frame, constraining improvisation (Magni et al., 2009). Yet the opposite holds under low turbulence, where organization-wide learning triggers improvisation in line with Mintzberg's (1994) assertion that emergent decision-making develops as a result of learning. This supports the value of information systems for firm improvisation in Asia (Zheng \& Mai, 2013) and offers critical insight into the role of turbulence. The interplay between organizational flexibility and learning remains unclear despite propositions in extant improvisation theory. This is due to neglect of key theoretical contingencies such as competitive turbulence. There is then a need to further investigate how knowledge resources drive improvisation under emerging economy conditions such as family ownership, patriarchal structures, and high levels of collectivism and power distance (Jiang, Peng, Yang, Xiaohua, \& Mutlu, 2015). Privatization, governance, and survival: MNE investments in private participation projects in emerging economies. Journal of World Business, 50: 294-301..

Developing this point further, there is a suggestion that improvisation may result in myopia (Vendelø, 2009) biasing decision-making through context-dependent knowledge. In a 
cultural context with high levels of collectivism and power distance, long-tenured managers may dominate decision-making owing to lower-status members’ conflict avoidance (Chi et al., 2009). This may help to explain the influence of tenure in reducing improvisation under low competitive turbulence, i.e. reducing creativity and locking the firm into path dependency. We encourage greater critical reflection on the role of demographics in Eastern settings, which may help to explain the observed research findings on tenure. For example, research on the relationship between organizational tenure diversity and innovation is shown to follow an inverted U-shaped pattern in Taiwan (Chi et al., 2009). Moreover, ownership is often concentrated within founding families that typically have high-tenured managers with long planning horizons (Tsai et al., 2006). A planning approach is often deemed an irrelevance in dynamic markets where emergent strategy-making processes, i.e. improvisation, should be prioritized (Mintzberg, 1994). In contrast, recent advocates of the planning approach stress its benefits for creativity and innovation, even in times of environmental upheaval (Covin et al., 1997). An important question to be considered then is how can managers reconcile improvisation and planning in an emerging economy context? Future research should explore this dichotomy. While improvisation may have both positive and negative organizational consequences (Hadida et al., 2014), it is a key theoretical lens for studying strategy emergence (Kyriakopoulos, 2011), or strategy process. In highly turbulent environments emergent strategy making is considered preferable over deliberate strategizing (Mintzberg \& Waters, 1985) due to the unpredictability of market environments. Emerging economy markets are characterized by frequent and surprising events and this would suggest that emergent strategy practices such as improvisation are a necessity. Yet the literature remains unclear as to whether improvisation thought can be extended from a study of Western economies to emerging economies. Taken collectively, prior studies and as a result our existing understanding of improvisation, are context-dependent. Though a growing body of work is uncovering the incidence and outcomes of improvisation, too few have accounted for different contexts (c.f. Kyriakopoulos, 2011). Given the distinct cultural differences that exist between Eastern and Western economies, we provide an initial indication of improvisation antecedents in an emerging economy under turbulence, which to the best of our knowledge has not been before undertaken. In doing so, the findings offer a key empirical contribution to improvisation theory addressing, in part, the field's incongruence and ensuing low cumulativeness (Hadida et al., 2014). 


\section{Managerial Relevance}

Strategic managers’ interest in improvisation has been increasing since its recognition as a crucial organizational competence for strategic change. Yet, the usefulness of improvisation in the organizational arena remains underdeveloped (Kyriakopoulos, 2011). Our study has a number of contributions for practice in middle-income economies.

First, support for organizational risk-taking should be a key consideration for strategic managers regardless of the levels of competitive turbulence faced. Whether improvising in the form of radical strategic shifts or tactical adjustments, a context that supports risk appears necessary for improvisation to occur. Linked to organizational risk-taking, the knowledge and skill base of managers needs to be exploited for improvisation to occur. This requires a supportive organizational context. Specifically, we suggest that a climate supportive of organizational risk-taking may promote values and beliefs that are tolerant of experimentation (and failure), which in turn may encourage the development of individual manager confidence to use their expertise on a real-time basis for intuitive responses. Collectively, these conditions will drive improvisation. Though managers need to be aware of the pitfalls of over-confidence and undue risk-taking (Li \& Tang, 2010).

Second, for organizations facing high competitive turbulence, organizational flexibility enables speed of response through improvisation. Spontaneity and creativity are central tenets of improvisation and can be enacted when conditions demand, but only within an internal context that supports fluidity and agility. This is of no concern to those firms facing low competitive turbulence, as improvisation is not driven by a firm's predilection for flexibility. Rather, organizational learning drives improvisation in low turbulence settings. Strategic managers should be mindful of this dynamic to ensure that a suitable framework is in place to boost flexibility or learning as appropriate pathways to strategic renewal, depending on their competitive landscape.

Third, under conditions of low competitive turbulence, managerial actions may be repeated over time in response to consistent cues from benign environments (Covin et al., 1997), which is magnified by the prominence of high-tenure managers in emerging economies (Chi et al., 2009). Over the course of long managerial tenure the repetition of actions can become embedded within organizational routines impeding the development of improvisation. 
Specifically, routine rigidity can reinforce alignment and constrain improvisation resulting in inertia, where repeated patterns of response involving interdependent activities become reinforced through structural embeddedness and repeated use (Gilbert, 2005). The recruitment of strategic managers, then, appears to be a crucial issue for realizing improvisation in stable competitive environments. Long tenured managers may be better served being part of a diversetenured team (Hughes et al., 2010). Too much diversity, however, may also be detrimental under this cultural context. Longer-tenured managers may dominate decision-making over members with less tenure (Chi et al., 2009), which based on the findings may reduce organizational improvisation. In contrast, managers operating within uncertain competitive conditions may draw on previous experiences of competitive threats, gained through exposure to such environmental conditions, for greater speed of response and thus perpetuate conditions of flexibility and change. Here, managers appear to symbiotically share the same flexibility espoused by their firms to remain competitive (Hughes et al., 2010). This appears to counteract the disadvantages of tenure experienced by organizations facing low competitive turbulence.

Fourth, widespread adoption of market-based policies by emerging economy governments raises important issues for the strategies adopted by private enterprises (Chari \& Banalieva, 2015). Emphasis is placed on developing strategic responses instead of adapting passively, extending the ideas of a firm's sustainable competitive advantages to an emerging economy context (Wright et al., 2005). If competitive advantage in changing markets depends critically upon strategic innovation then the sources of strategic innovation need to be considered (Grant, 2003). Improvisation is shown in the literature as a means to achieve strategic renewal demonstrating its relevance to emerging economies. While deliberate decision-making may emphasize emerging economy characteristics of centralization and hierarchy, more emergent improvisation can encourage collective action and convergent behaviour (Mintzberg \& Waters, 1985), which is seemingly suited to a collectivist context. As seen with similar middle-income economies (e.g., Taiwan), research-intensive firms have become an important production source for global high-technology products (e.g., Chi et al., 2009). When an environment is too complex to comprehend, or too imposing to defy, allowing managers to act before everything is fully understood and to take actions that uncover where strengths and weaknesses really lie (Mintzberg \& Waters, 1985) is pertinent. By developing our understanding of the drivers of 
improvisation in a middle-income economy, we establish a foundation for theory development reducing the ratio between issues for further research and implications for practice.

\section{Limitations and Future Research}

This study carries certain limitations. First, using a cross-sectional design does not allow causality to be asserted from the data. We suggest a longitudinal study is a necessary next step. Second, judgments about improvisation and its drivers, although qualified, have been reported by a single informant. Although no common method problems were found, it is recognized that data generated from multiple informants is preferred with the proviso that including less knowledgeable informants can reduce response accuracy (Huber \& Power, 1985). Third, this study sampled research-intensive firms from Malaysia and caution must be exercised against generalizing the results into industry contexts significantly beyond those described here. Extending improvisation research to other industries and emerging economies would be a useful avenue for research, particularly in advancing the findings presented.

A further promising research area is the interplay between planning and improvisation at the organization-level. While emerging economies may have a predilection toward planning (Tsai et al., 2006), all viable strategies have emergent and deliberate qualities (Mintzberg \& Waters, 1985) and therefore understanding how improvisation can be generated but also, its reconciliation with planning is necessary to explore viable strategy making in emerging economies. Miner et al. (2001, p. 305) suggest that "improvised activities often occur outside organized routines or formal plans”, but this implies that firms either plan or improvise, but do not engage in both simultaneously (Nemkova et al., 2012). Managers may not have to choose to either plan or improvise, rather there is a need to shift focus of research from such trade-offs (either/or) to paradoxical (both/and) thinking (Dunbar \& Ahlstrom, 1995). The additional analysis undertaken suggests a fruitful area for future research would be to examine the interplay between planning and improvisation during different stages of an organization's life-cycle, since older firms and those with longer tenured managers improvise less and so become more inert.

\section{Conclusion}

This paper sought to address the research question: what drives organizational improvisation in an emerging economy under conditions of turbulence? The results uncover core 
organizational and managerial antecedents of improvisation, irrespective of the environment conditions, and additional drivers emerging under high versus low levels of competitive turbulence. Additional analysis suggests that firms are less inclined to improvise when averse to risk-taking, lack flexibility, and engage less in organizational learning. We shed light on the drivers of improvisation in the different competitive settings of an emerging economy, extending the study of improvisation in developed economies to the characteristics of firms in Malaysia. Improvisation research is still in its infancy and it is not a given that existing research findings derived from research largely conducted in developed economies will translate across to emerging economies and their firms (Young et al., 2014). With that in mind, while this current work addresses antecedents of improvisation, more is needed to understand how this translates into performance outcomes for these firms, competitive advantage, and ultimately economic growth to avoid the middle-income trap.

\section{Acknowledgements}

The authors thank Professor Xiaohui Liu for her valuable comments on an earlier draft of this paper and the anonymous reviewers for their insightful suggestions. The authors also thank Professor David Ahlstrom for his editorial guidance throughout the review process. 


\section{References}

Abrahamson, E. (2008). 22 things I hate: Mini rants on management research. Journal of Management Inquiry, 17(4), 422-425.

Acemoglu, D. \& Johnson, S. (2005). Unbundling institutions. Journal of Political Economy, 113(5), 949-995.

Ahlstrom, D. (2010). Innovation and growth: How business contributes to society. Academy of Management Perspectives, 24(3), 10-23.

Ahlstrom, D. \& Nair, A. (2000). Exploring the concept of know-why and its impact on biomedicine’s transformation. Asia Pacific Journal of Management, 17(2), 331-353.

Ahlstrom, D., Young, M. N., Chan, E. S. \& Bruton, G. D. (2004). Facing constraints to growth? Overseas Chinese entrepreneurs and traditional business practices in East Asia. Asia Pacific Journal of Management, 21(3), 263-285.

Alvarez, S. A., Barney, J. B., \& Newman, A. M. (2015). The poverty problem and the industrialization solution. Asia Pacific Journal of Management, 32(1),: 23-37.

Aram, J. D., \& Walochik, K. (1996). Improvisation and the Spanish manager. International Studies of Management and Organization, 26(4), 73-89.

Atkinson, J. (1985). Flexibility: planning for an uncertain future. Manpower Policy and Practice, 1(Summer), 26-29.

Auh, S., \& Menguc, B. (2007). Performance implications of the direct and moderating effects of centralization and formalization on customer orientation. Industrial Marketing Management, 36(8), 1022-1034.

Baird, I. S., \& Thomas, H. (1985). Toward a contingency model of strategic risk taking, Academy of Management Review, 10(2), 230-243.

Bakken, B. E. (2008). On improving dynamic decision-making: implications from multipleprocess cognitive theory. Systems Research and Behavioral Science, 25(4), 493-501.

Bergh, D. D., \& Ngah-Kiing Lim, E. (2008). Learning how to restructure: Absorptive capacity and improvisational views of restructuring actions and performance. Strategic Management Journal, 29(6), 593-616.

Bingham, C. B. (2009). Oscillating improvisation: How entrepreneurial firms create success in foreign market entries over time. Strategic Entrepreneurship Journal, 3(4), 321-345.

Bollen, K. A. (1989). Structural Equations with Latent Variables. New York: Wiley. 
Chari, M. D., \& Banalieva, E. R. (2015). How do pro-market reforms impact firm profitability? The case of India under reform. Journal of World Business, 50(2): 357-367.

Chelariu, C., Johnston, W. J., \& Young, L. (2002). Learning to improvise, improvising to learn a process of responding to complex environments. Journal of Business Research, 55(1), 141-147.

Chi, N.-W., Huang, Y.-M., \& Lin, S.-C. (2009). A double-edged sword? Exploring the curvilinear relationship between organizational tenure diversity and team innovation: The moderating role of team-oriented HR practices. Group \& Organization Management, 34(6), 698-726.

Conway, J. M., \& Lance, C. E. (2010). What reviewers should expect from authors regarding common method bias in organizational research. Journal of Business and Psychology, 25(3), 325-334.

Covin, J. G., Slevin, D. P. \& Schultz, R. L. (1997). Top management decision sharing and adherence to plans. Journal of Business Research, 40(1), 21-36.

Crossan, M. M., \& Sorrenti, M. (2002). Making sense of improvisation. In Kamoche, K. N., Cunha, M. P., \& Cunha, J. V. Organizational Improvisation. London: Routledge.

Cunha, M. P. (2005). Adopting or adapting? The tension between local and international mindsets in Portuguese management. Journal of World Business, 40(2), 188-202.

Cunha, M. P., \& Cunha, J. V. (2003). Organizational improvisation and change: Two syntheses and a filled gap. Journal of Organizational Change, 16(2), 169-185.

Cunha, M.P., Cunha, J.V., and Kamoche, K. (1999). Organizational improvisation: What, when, how and why. International Journal of Management Review, 1(3), 299-341.

Cunha, J. V., Kamoche, K. N., \& Cunha, M.P. (2002). Once again: What, how and why - a prospectus for research in organizational improvisation. In Kamoche, K. Cunha, M. P., \& Cunha, J. V. (2002). Organizational Improvisation. London: Routledge.

Dane, E. (2010). Reconsidering the trade-off between expertise and flexibility: A cognitive entrenchment perspective. Academy of Management Review, 35(4), 579-603.

Dunbar, R. L. M. \& Ahlstrom, D. (1995). Seeking the institutional balance of power: Avoiding the power of a balanced view. Academy of Management Review, 20(1), 171-192.

Eisenhardt, K. M. (1997). Strategic decision and all that jazz. Business Strategy Review, 8(3), 13. 
Eisenhardt, K. M., \& Tabrizi, B. N. (1995). Accelerating adaptive processes: product innovation in a global computer industry. Administrative Science Quarterly, 40(1), 84-110.

Gibbons, P. T., \& O'Connor, T. (2005). Influences on strategic planning processes among Irish SMEs. Journal of Small Business Management, 43(2), 170-187.

Gilbert, C. G. (2005). Unbundling the structure of inertia: resource versus routine rigidity. Academy of Management Journal, 48(5), 741-763.

Gill, I. \& Kharas, H. (2007). An East Asian Renaissance: Ideas for economic growth. Washington, DC: The World Bank.

Greve, H. 2003. A behavioral theory of R\&D expenditures and innovations: Evidence from shipbuilding. Academy of Management Journal, 46, 685-702.

Hadida, A. L., Tarvainen, W., \& Rose, J. (2014). Organizational improvisation: A consolidating review and framework. International Journal of Management Reviews. DOI: 10.1111/ijmr.12047

Hambrick, D. C., \& Fukutomi, G. D. S. (1991). The seasons of a CEO's tenure. Academy of Management Review, 16(4), 719-742.

Hamel, G. (2012). What matters now: How to win in a world of relentless change, ferocious competition, and unstoppable innovation. San Francisco: Jossey-Bass.

Hodgkinson, G. P., Sadler-Smith, E., Burke, L. A., Claxton, G., \& Sparrow, P. R. (2009). Intuition in organizations: Implications for Strategic Management. Long Range Planning, 42(3), 277-297.

Hu, L., \& Bentler, P. M. (1999). Cutoff criteria for fit indices in covariance structure analysis: Conventional criteria versus new alternatives. Structural Equation Modeling, 6(1), 1-55.

Huber, G. P., \& Power, D. J. (1985). Retrospective report of strategic-level managers: Guidelines for increasing their accuracy. Strategic Management Journal, 6(2), 171-180.

Hughes, M., Morgan, R. E., Ireland, R. D., \& Hughes, P. (2014). Social capital and learning advantages: A problem of absorptive capacity. Strategic Entrepreneurship Journal, 8(3), 214-233.

Hughes, P., Hughes, M., \& Morgan, R. E. (2010). Why do product-market strategies fail? A sociostructural examination under conditions of adherence. Group \& Organization Management, 35(5), 606-635. 
Hughes, P., Morgan, R. E., \& Kouropalatis, Y. (2008). Market knowledge diffusion and business performance. European Journal of Marketing, 42(11/12), 1372-1395.

Jiang, Y., Peng, M. W., Yang, X., \& Mutlu, C. (2015). Privatization, governance, and survival: MNE investments in private participation projects in emerging economies. Journal of World Business, 50: 294-301.

Jones, R. A., Rafferty, A. E., \& Griffin, M. A. (2006). The executive coaching trend: Towards more flexible executives. Leadership \& Organization Development Journal, 27(7), 584596.

Kamoche, K., Cunha, M. P., \& Cunha, J. V. (2003). Towards a theory of organizational improvisation: Looking beyond jazz metaphor. Journal of Management Studies, 40(8), 2023-2051.

Kyriakopoulos, K. (2011). Improvisation in product innovation: The contingent role of market information sources and memory types. Organization Studies, 32(8), 1051-1078.

Krohmer, H., Homburg, C., \& Workman, J. P. (2002). Should marketing be cross-functional? Conceptual development and international empirical evidence. Journal of Business Research, 55(6), 451-465.

Leybourne, S., \& Sadler-Smith, E. (2006). The role of intuition and improvisation in project management. International Journal of Project Management, 24(6), 483-492.

Li, J., \& Tang, Y. I. (2010). CEO hubris and firm risk taking in China: The moderating role of managerial discretion. Academy of Management Journal, 53(1), 45-68.

Liu, X., Hodgkinson, I. R., \& Chuang, F. M. (2014). Foreign competition, domestic knowledge base and innovation activities: Evidence from Chinese high-tech industries. Research Policy, 43(2), 414-422.

Liu, Y., Wang, L. C., Zhao, L. \& Ahlstrom, D. (2013). Board turnover in Taiwan's public firms: An empirical study. Asia Pacific Journal of Management, 30(4): 1059-1086.

Magni, M., Proserpio, L., Hoegl, M., \& Provera, B. (2009). The role of team behavioral integration and cohesion in shaping individual improvisation. Research Policy, 38(6), 1044-1053.

Magni, M., Provera, B., \& Proserpio, L. (2010). Individual attitude toward improvisation in information systems development. Behaviour \& Information Technology, 29(3), 245-255.

March, J. (1994). Primer on decision making: How decisions happen. New York: Free Press. 
Miller, D. (1991). Stale in the saddle: CEO tenure and the match between organization and environment. Management Science, 37(1), 34-52.

Miner, A. S., Bassoff, P., \& Moorman, C. (2001). Organizational improvisation and learning: A field study. Administrative Science Quarterly, 46(2), 304-333.

Mintzberg, H. (1979). The Structuring of Organizations. Englewood Cliffs: Prentice-Hall.

Mintzberg, H. (1994) The Rise and Fall of Strategic Planning. London: Prentice-Hall.

Mintzberg, H., \& Waters, J. A. (1985). Of strategies, deliberate and emergent. Strategic Management Journal, 6(3), 257-272.

Moorman, C., \& Miner, A. S. (1998a). Organizational improvisation and organizational memory. Academy of Management Review, 23(4), 698-723.

Moorman, C., \& Miner, A. S. (1998b). The convergence between planning and execution: Improvisation in new product development. Journal of Marketing, 62(3), 1-20.

Nemkova, E., Souchon, A. L., \& Hughes, P. (2012). Export decision-making orientation: an exploratory study. International Marketing Review, 29(4), 349-378.

Podsakoff, P. M., MacKenzie, S. B., Lee, J-Y., \& Podsakoff, N.P. (2003). Common method biases in behavioural research: A critical review of the literature and recommended remedies. Journal of Applied Psychology, 88(5), 879-903.

Singh J. V. (1986). Performance, slack, and risk taking in organizational decision making. Academy of Management Journal, 29(3), 562-585.

Slevin, D. P., \& Covin, J.G. (1997). Strategy formation patterns, performance and the significance of context. Journal of Management, 23(2), 189-209.

Tsai, W. H., Hung, J. H., Kuo, Y. C., \& Kuo, L. (2006). CEO tenure in Taiwanese family and nonfamily firms: An agency theory perspective. Family Business Review, 19(1), 11-28.

Todd, P., \& Peetz, D. (2001). Malaysian industrial relations at century’s turn: Vision 2020 or a spectre of the past? International Journal of Human Resource Management, 12(8), 13651382.

Vendelø, M. T. (2009). Improvisation and learning in organizations: An opportunity for future empirical research. Management Learning, 40(4), 449-456.

Vera, D. \& Crossan, M.M. (1999). Improvisation: a theoretical model of its dimensions, antecedents, outcomes, and moderating variables. Richard Ivey School of Business Working paper 1999-10, London, ON, Canada. 
Vera, D., \& Crossan, M. (2004). Theatrical improvisation: Lessons for organizations. Organization Studies, 25(5), 727-749.

Vera, D., \& Crossan, M. (2005). Improvisation and innovative performance in teams. Organization Science, 16(3), 203-224.

Weick, K. E. (1998). Improvisation as a mindset for organizational analysis. Organization Science, 9(5), 543-555.

Wright, M., Filatotchev, I., Hoskisson, R. E., \& Peng, M. W. (2005). Strategy research in emerging economies: challenging the conventional wisdom. Journal of Management Studies, 42(3), 1-33.

Young, M.N., Tsai, T., Wang, X., Liu, S. \& Ahlstrom, D. 2014. Strategy in emerging economies and the theory of the firm. Asia Pacific Journal of Management, 31(2), 331-354.

Zheng, Y., \& Mai, Y. (2013). A contextualized transactive memory system view on how founding teams respond to surprises: Evidence from China. Strategic Entrepreneurship Journal, 7(3), 197-213. 
Figure 1 A model of organizational improvisation under conditions of turbulence

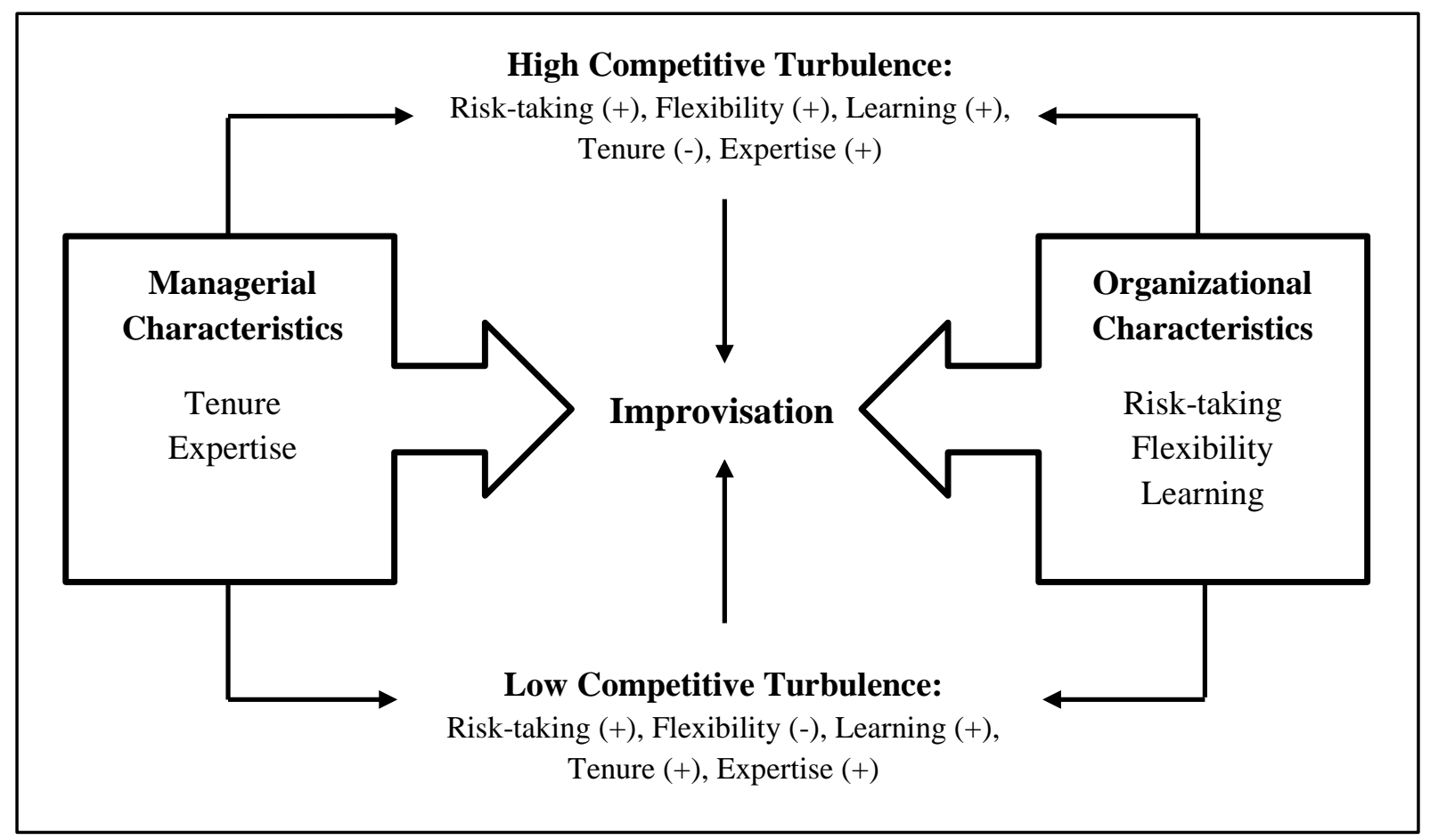


Table 1 Measurement item properties

\begin{tabular}{|c|c|c|c|}
\hline Construct $^{\mathrm{a}}$ & Measurement Item & $\begin{array}{l}\text { Standardized } \\
\text { Factor Loading }\end{array}$ & t-value \\
\hline \multirow{3}{*}{$\begin{array}{l}\text { Organizational } \\
\text { risk-taking }\end{array}$} & ...heavy reliance on innovation & .78 & 9.05 \\
\hline & ...heavy R\&D & .74 & 8.55 \\
\hline & ...high risk, high return investments & .69 & 7.81 \\
\hline \multirow{6}{*}{$\begin{array}{l}\text { Organizational } \\
\text { flexibility }\end{array}$} & ...adapted to change with minimal stress & .72 & 9.02 \\
\hline & ...adapted your company strategy adequately to changes in the & & \\
\hline & business environment & .91 & 12.67 \\
\hline & ....adapted your company strategy adequately to changes in & & \\
\hline & competitors’ product-market strategies & .83 & 11.10 \\
\hline & $\begin{array}{l}\text {...adapted your company strategy quickly to the changing needs of } \\
\text { customers }\end{array}$ & .79 & 10.24 \\
\hline \multirow{3}{*}{$\begin{array}{l}\text { Organizational } \\
\text { learning }\end{array}$} & ...readily shared information within organization & .74 & 8.77 \\
\hline & ...receive information about other departments’ activities & .75 & 8.88 \\
\hline & ...information on external environment & .82 & 9.96 \\
\hline \multirow{3}{*}{$\begin{array}{l}\text { Managerial } \\
\text { expertise }\end{array}$} & I am aware of the critical managerial issues that affect my work & .76 & 8.82 \\
\hline & I am current and knowledgeable about my field of work & .68 & 7.67 \\
\hline & I have knowledge in diverse fields & .58 & 6.33 \\
\hline \multirow{5}{*}{$\begin{array}{r}\text { Competitive } \\
\text { turbulence }\end{array}$} & Competition in our industry is cut-throat & .70 & 8.34 \\
\hline & There are many ‘promotion wars’ in our industry & .73 & 8.83 \\
\hline & Anything that one competitor can offer, others can match readily & .72 & 8.70 \\
\hline & Price competition is a hallmark of our industry & .78 & 9.71 \\
\hline & One hears of a new competitive move almost every day & .73 & 8.91 \\
\hline \multirow{3}{*}{$\begin{array}{l}\text { Organizational } \\
\text { improvisation }\end{array}$} & ...make a strategic plan and execute it at the same time & .75 & 9.38 \\
\hline & $\begin{array}{l}\text {...engage in spontaneous actions to create strategy within time } \\
\text { pressures }\end{array}$ & .81 & 10.36 \\
\hline & ...make intuitive judgments for taking actions & .85 & 11.09 \\
\hline Tenure & Years with the company & $-{ }^{b}$ & $-{ }^{b}$ \\
\hline
\end{tabular}


Table 2 Construct robustness and descriptive statistics

\begin{tabular}{|c|c|c|c|c|c|c|c|c|c|c|}
\hline & $\alpha$ & $\mathbf{C R}$ & AVE & $\mathbf{X 1}$ & $\mathrm{X} 2$ & X3 & $\mathrm{X} 4$ & X5 & X6 & $\mathbf{X 7}$ \\
\hline $\begin{array}{c}\text { X1 Organizational } \\
\text { risk-taking }\end{array}$ & .79 & .78 & .54 & $.73^{a}$ & & & & & & \\
\hline $\begin{array}{c}\text { X2 Organizational } \\
\text { flexibility }\end{array}$ & .88 & .89 & .67 & $.37 * *$ & .82 & & & & & \\
\hline $\begin{array}{l}\text { X3 Organizational } \\
\text { learning }\end{array}$ & .81 & .81 & .59 & $.21^{*}$ & $.45^{* *}$ & .77 & & & & \\
\hline $\begin{array}{c}\text { X4 Managerial } \\
\text { expertise }\end{array}$ & .71 & .72 & .46 & $.29 * *$ & $.50 * *$ & $.47 * *$ & .68 & & & \\
\hline X5 Tenure & $\mathrm{n} / \mathrm{a}$ & $\mathrm{n} / \mathrm{a}$ & $\mathrm{n} / \mathrm{a}$ & -.14 & .03 & .05 & .13 & $n / a$ & & \\
\hline $\begin{array}{l}\text { X6 Competitive } \\
\text { turbulence }\end{array}$ & .86 & .85 & .54 & .05 & .13 & .04 & .01 & -.08 & .73 & \\
\hline $\begin{array}{l}\text { X7 Organizational } \\
\text { improvisation }\end{array}$ & .84 & .85 & .65 & $.49 * *$ & $.52 * *$ & $.38 * *$ & $.54 * *$ & -.12 & .05 & .81 \\
\hline Mean & & & & 4.78 & 5.40 & 4.97 & 5.65 & 8.03 & 4.83 & 5.35 \\
\hline Standard Deviation & & & & 1.17 & 0.86 & 1.11 & 0.83 & 7.26 & 1.19 & 0.93 \\
\hline 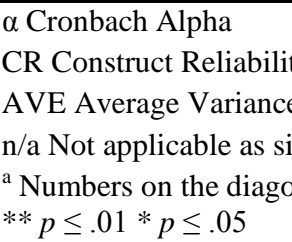 & tracte & $\begin{array}{l}\text { ble } \\
\text { root }\end{array}$ & & & & & & & & \\
\hline
\end{tabular}


Table 3 Regression results for high and low competitive turbulence

\begin{tabular}{|c|c|c|c|c|c|c|}
\hline & $\begin{array}{c}\text { Independent } \\
\text { Variable } \\
\end{array}$ & & $\begin{array}{c}\text { Dependent } \\
\text { Variable }\end{array}$ & $\begin{array}{c}\text { Standardized } \\
\text { Coefficients }\end{array}$ & $t$-value & $\begin{array}{c}\text { Hypotheses } \\
\text { Support }\end{array}$ \\
\hline \multicolumn{7}{|c|}{ Regression Model 1: High competitive turbulence } \\
\hline Hypothesis 1 & $\begin{array}{l}\text { Organizational } \\
\text { risk-taking }\end{array}$ & $\rightarrow$ & $\begin{array}{l}\text { Organizational } \\
\text { improvisation }\end{array}$ & 0.36 & $3.47 * *$ & Supported \\
\hline Hypothesis 2a & $\begin{array}{l}\text { Organizational } \\
\text { flexibility }\end{array}$ & $\rightarrow$ & $\begin{array}{l}\text { Organizational } \\
\text { improvisation }\end{array}$ & 0.40 & $3.70^{* *}$ & Supported \\
\hline Hypothesis 3a & $\begin{array}{l}\text { Organizational } \\
\text { learning }\end{array}$ & $\rightarrow$ & $\begin{array}{l}\text { Organizational } \\
\text { improvisation }\end{array}$ & -0.12 & -1.18 & n.s. \\
\hline Hypothesis 4a & Tenure & $\rightarrow$ & $\begin{array}{l}\text { Organizational } \\
\text { improvisation }\end{array}$ & -0.02 & -0.25 & n.s. \\
\hline Hypothesis 5a & $\begin{array}{c}\text { Managerial } \\
\text { expertise }\end{array}$ & $\rightarrow$ & $\begin{array}{l}\text { Organizational } \\
\text { improvisation }\end{array}$ & 0.25 & $2.26^{*}$ & Supported \\
\hline \multicolumn{7}{|c|}{ Regression Model 2: Low competitive turbulence } \\
\hline Hypothesis 1 & $\begin{array}{l}\text { Organizational } \\
\text { risk-taking }\end{array}$ & $\rightarrow$ & $\begin{array}{l}\text { Organizational } \\
\text { improvisation }\end{array}$ & 0.32 & $3.15^{* *}$ & Supported \\
\hline Hypothesis 2b & $\begin{array}{l}\text { Organizational } \\
\text { flexibility }\end{array}$ & $\rightarrow$ & $\begin{array}{l}\text { Organizational } \\
\text { improvisation }\end{array}$ & 0.02 & 0.14 & n.s. \\
\hline Hypothesis 3b & $\begin{array}{l}\text { Organizational } \\
\text { learning }\end{array}$ & $\rightarrow$ & $\begin{array}{l}\text { Organizational } \\
\text { improvisation }\end{array}$ & 0.28 & $2.42 * *$ & Supported \\
\hline Hypothesis 4b & Tenure & $\rightarrow$ & $\begin{array}{l}\text { Organizational } \\
\text { improvisation }\end{array}$ & -0.26 & $-2.80 * *$ & Refuted \\
\hline Hypothesis 5b & $\begin{array}{c}\text { Managerial } \\
\text { expertise }\end{array}$ & $\rightarrow$ & $\begin{array}{l}\text { Organizational } \\
\text { improvisation }\end{array}$ & 0.36 & $3.03 * *$ & Supported \\
\hline
\end{tabular}

Notes: ${ }^{* *} p \leq 0.01,{ }^{*} p \leq 0.05$. 
Table 4 ANOVA results for high and low improvisation

\begin{tabular}{lccc}
\hline Internal Characteristics & \multicolumn{2}{c}{ Improvisation Group (Mean [SD]) } & $\begin{array}{c}\text { F-value } \\
\text { Between Groups }\end{array}$ \\
\hline Organizational Risk-taking & $3.97(1.24)$ & $5.06(1.01)$ & $25.10^{* *}$ \\
Organizational Flexibility & $4.79(0.74)$ & $5.62(0.80)$ & $27.25^{* *}$ \\
Organizational Learning & $4.36(1.22)$ & $5.18(0.99)$ & $15.10^{* *}$ \\
Managerial Tenure & $9.52(8.97)$ & $7.73(6.56)$ & 1.81 \\
Managerial Expertise & $5.04(0.89)$ & $5.86(0.70)$ & $28.57^{* *}$ \\
& & & \\
Additional Characteristics & & & $3.18 \dagger$ \\
Size (Previous year sales turnover & & & $4.34^{*}$ \\
[US\$000]) & $579663.46(2388217.72)$ & $40442.58(194421.58)$ & $14.83(15.06)$ \\
Years of Operation & $21.78(20.24)$ & $12.99(8.11)$ & 0.01 \\
Manager's Industry Experience & $13.06(9.62)$ & $41.11(9.74)$ & 0.35 \\
Manager Age & $39.94(10.41)$ & $3.23(0.74)$ & 1.84 \\
Manager Education & $3.03(0.73)$ & & \\
\hline Notes: & & & \\
\hline
\end{tabular}

Notes: $* * p \leq 0.01 ; * p \leq 0.05 ; \dagger p \leq 0.10$. 
Appendix A Testing for common method variance through the partial correlation procedure with a marker variable

\begin{tabular}{|c|c|c|c|c|c|c|c|}
\hline & & & & \multicolumn{2}{|c|}{ Original Results } & \multicolumn{2}{|c|}{$\begin{array}{l}\text { Results after partialling out } \\
\text { correlation of marker variable } \\
\text { from study variables }\end{array}$} \\
\hline & \multicolumn{2}{|l|}{$\begin{array}{c}\text { Independent } \\
\text { Variable }\end{array}$} & $\begin{array}{c}\text { Dependent } \\
\text { Variable } \\
\end{array}$ & $\begin{array}{c}\text { Standardized } \\
\text { Coefficients }\end{array}$ & $t$-value & $\begin{array}{c}\text { Standardized } \\
\text { Coefficients }\end{array}$ & $t$-value \\
\hline \multicolumn{8}{|c|}{ Regression Model 1: High competitive turbulence } \\
\hline $\mathrm{H} 1$ & $\begin{array}{l}\text { Organizational } \\
\text { risk-taking }\end{array}$ & $\rightarrow$ & $\begin{array}{l}\text { Organizational } \\
\text { improvisation }\end{array}$ & 0.36 & $3.47 * *$ & 0.34 & $3.26^{* *}$ \\
\hline $\mathrm{H} 2 \mathrm{a}$ & $\begin{array}{l}\text { Organizational } \\
\text { flexibility }\end{array}$ & $\rightarrow$ & $\begin{array}{l}\text { Organizational } \\
\text { improvisation }\end{array}$ & 0.40 & $3.70 * *$ & 0.40 & $3.59 * *$ \\
\hline НЗа & $\begin{array}{l}\text { Organizational } \\
\text { learning }\end{array}$ & $\rightarrow$ & $\begin{array}{l}\text { Organizational } \\
\text { improvisation }\end{array}$ & -0.12 & -1.18 & -0.13 & -1.24 \\
\hline $\mathrm{H} 4 \mathrm{a}$ & Tenure & $\rightarrow$ & $\begin{array}{l}\text { Organizational } \\
\text { improvisation }\end{array}$ & -0.02 & -0.25 & 0.01 & 0.06 \\
\hline H5a & $\begin{array}{l}\text { Managerial } \\
\text { expertise }\end{array}$ & $\rightarrow$ & $\begin{array}{l}\text { Organizational } \\
\text { improvisation }\end{array}$ & 0.25 & $2.26 *$ & 0.26 & $2.35 * *$ \\
\hline \multicolumn{8}{|c|}{ Regression Model 2: Low competitive turbulence } \\
\hline $\mathrm{H} 1$ & $\begin{array}{l}\text { Organizational } \\
\text { risk-taking }\end{array}$ & $\rightarrow$ & $\begin{array}{l}\text { Organizational } \\
\text { improvisation }\end{array}$ & 0.32 & $3.15^{* *}$ & 0.32 & $3.18 * *$ \\
\hline $\mathrm{H} 2 \mathrm{~b}$ & $\begin{array}{l}\text { Organizational } \\
\text { flexibility }\end{array}$ & $\rightarrow$ & $\begin{array}{l}\text { Organizational } \\
\text { improvisation }\end{array}$ & 0.02 & 0.14 & 0.02 & 0.13 \\
\hline H3b & $\begin{array}{l}\text { Organizational } \\
\text { learning }\end{array}$ & $\rightarrow$ & $\begin{array}{l}\text { Organizational } \\
\text { improvisation }\end{array}$ & 0.28 & $2.42 * *$ & 0.27 & $2.27 *$ \\
\hline $\mathrm{H} 4 \mathrm{~b}$ & Tenure & $\rightarrow$ & $\begin{array}{l}\text { Organizational } \\
\text { improvisation }\end{array}$ & -0.26 & $-2.80 * *$ & -0.25 & $-2.59 * *$ \\
\hline H5b & $\begin{array}{l}\text { Managerial } \\
\text { expertise }\end{array}$ & $\rightarrow$ & $\begin{array}{l}\text { Organizational } \\
\text { improvisation }\end{array}$ & 0.36 & $3.03 * *$ & 0.37 & $3.04 * *$ \\
\hline
\end{tabular}

Notes: ${ }^{* *} p \leq 0.01,{ }^{*} p \leq 0.05$. 